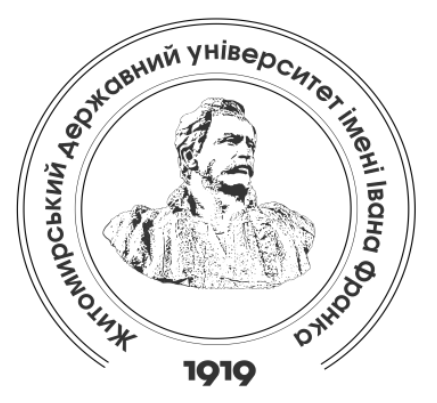

Zhytomyr Ivan Franko State University Journal. Pedagogical Sciences. Vol. 1 (100)

Вісник Житомирського державного університету імені Івана Франка. Педагогічні науки. Вип. 1 (100)

ISSN (Online): 2664-0155

UDC 378.011.3-051:373.3]:81'243

DOI 10.35433/pedagogy.1(100).2020.61-71

\title{
ANALYSIS OF THE CURRENT STATE OF FORMING INTENDING PRIMARY SCHOOL TEACHERS' FOREIGN LANGUAGE COMMUNICATIVE COMPETENCE IN THE PROCESS OF PROFESSIONAL TRAINING
}

\section{O. Pinchuk*}

Current state of forming intending primary school teachers' foreign language communicative competence in the process of professional training according to the legislative framework of Ukraine is analysed in the article. Changes and new social demands on the identity of primary school teachers, including the need to teach a foreign language together with other subjects, necessitate the improvement and achievement of the effectiveness of the foreign language education process in the primary education faculties in pedagogical institutions of higher education. Pedagogical higher education should aim to stimulate and motivate students to acquire a foreign-language professionally-oriented communication competence. The analysis of the issue under study in the state legal documents regulating the primary education specialists training, indicates that the whole documentary base orientates the primary school teachers' professional education to the development of their communication skills and proves the importance of forming the foreign language communicative competence of intending primary school teachers. Studying the educational programs of a number of higher education pedagogical establishments gives grounds to state that the professional training educational programs of bachelors on the specialty 013 "Primary Education" are aimed at realization of state requirements for defined competence formation. The article is based on the analysis of the bachelor degree programs for specialty 013 "Primary Education" in higher education institutions of Ukraine; a number of courses, the didactic potential of which has objectively laid out opportunities for forming the foreign language communicative competence are distinguished. In the process of studying the courses, integration with foreign language can be used in the context of modern requirements for professional training.

Key words: foreign language communicative competence, intending primary school teachers, professional training, legislative framework, educational program

\footnotetext{
${ }^{*}$ Candidate of Pedagogical Sciences (PhD in Pedagogy), Senior Educator

(Oleksandr Dovzhenko Hlukhiv National Pedagogical University)

pinchukiryna6@gmail.com

ORCID: 0000-0002-1376-3977
} 


\section{АНАЯІЗ СУЧАСНОГО СТАНУ ФОРМУВАННЯ ІНШОМОВНОї KOMУНIKАТИВНОÏ KОМПЕТЕНТНОСТI МАЙБУТНIX УЧИТЕАIВ ПОЧАТКОВОЇ ШКОАИ У ПРОЦЕСІ ПРОФЕСІЙНОЇ ПІДГОТОВКИ}

\section{I. О. Пінчук}

У статті проаналізовано сучасний стан формування іншомовної комунікативної компетентності майбутніх учителів початкової школи у проиесі професійної підготовки відповідно до законодавчої бази Украӥни. Зміни й нові суспільні вимоги до особистості вчителя початкової школи, зокрема необхідність разом з іншими предметами навчати іноземної мови, зумовлюють потребу вдосконалення та досягнення ефективності освітнього процесу з іноземної мови на факультетах початкової освіти в педагогічних закладах вищої освіти. Педагогічна вища освіта має бути спрямована на стимулювання та мотивацію до оволодіння іншомовною професійно-зорієнтованою комунікативною компетентністю. Проведений аналіз досліджуваної проблеми в державних документах, шо регламентують підготовку фахівиів початкової освіти, засвідчуе, шо вся документальна база орієнтуе професійну підготовку фрахівия початкової освіти на розвиток його комунікативності й переконуе у важливості формування іншомовної комунікативної компетентності майбутніх учителів початкової школи. Вивчення освітніх програм низки педагогічних вишів дає підставу стверджувати, шо освітні програми професійної підготовки бакалаврів спеиіальності 013 "Початкова освіта" спрямовані на реалізацію державних вимог шјодо формування визначеної компетентності. В статті на основі аналізу освітніх програм підготовки бакалаврів за спеиіальністю 013 "Початкова освіта" ЗВО Украйни, виокремлено низку дисииплін, дидактичний потениіал яких мае об'єктивно закладені можливості для формування іншомовної комунікативної компетентності, в проиесі вивчення яких, відповідно до сучасних вимог, можна використати інтеграцію з іноземною мовою в контексті сучасних вимог до фахової підготовки.

Ключові слова: іншомовна комунікативна компетентність, майбутні вчителі початкової школи, професійна підготовка, законодавча база, освітня програма.

Introduction of the issue. Forming intending primary school teachers' foreign language communicative competence according to the process of primary school professionals' training is regulated by the government documents, in particular the provisions of the Law of Ukraine "On Education" [7], the Law of Ukraine "On Higher Education" [4], the National Strategy of developing education in Ukraine for the period up to 2021 [12], the State standard of primary general education [13], the Concept of the new Ukrainian school [8]. The conceptual grounds of the new paradigm of national education is also defined in the Law "On Amendments to Certain Legislative Acts of Ukraine on Improving Education Activities in the field of Higher Education" [6], new higher education standards based on the
"Recommendations of the European Parliament and the Council of Europe according to forming core competences of lifelong learning" [16].

Aim of research is to analyse the state of forming students' foreign language communicative competence in the process of professional training in higher education pedagogical institutions of Ukraine regarding its compliance with the standards of state national documents and educational programs.

Results and discussion. In the National Strategy for the Development of Education in Ukraine for the period up to 2021 [12] the purposes, strategic directions and main tasks of implementing the state policy of the education are defined. First of all, an important step is to update the 
legislative framework in the field of education.

The Law "On Amendments to Certain Legislative Acts of Ukraine on Improving Education Activities in the field of Higher Education", signed on January 13, 2020, states that "higher education standards for each specialty are developed by the central executive authority in the field of education and science, taking into account sectoral state bodies proposals that provide for the formation and implementation of state policy in relevant areas, sectoral associations of employers' organizations and approve them in agreement with the National Agency for Quality Assurance of Higher Education" [6].

In the list of subject-specific and general competences of the sphere of education according to the Bologna classification, presented in the methodological recommendations of the educational programs development, edited by V. Kremen [17], the formation of communication skills is obligatory.

The new generation of standards reflects the principles of defining specialist requirements recommended by the Bologna Process and the European Commission's International Project on the Harmonization of Educational Structures in Europe (TUNING) and is based on a competent approach.

In the methodological guidelines for the development of higher education standards [11] three blocks of competences are referred: integral competence is a general description of the qualification level, which reflects the main competence characteristics of the level in relation to training or professional activity; general ones, which are universal competences that are independent and have no strong bound to any particular sphere, but important for the successful further professional and social activity in various fields of educational activity, as well as personal development of the specialist; special competences that depend on the subject area and are also important for successful professional activity in a particular specialty (Fig. 1.).

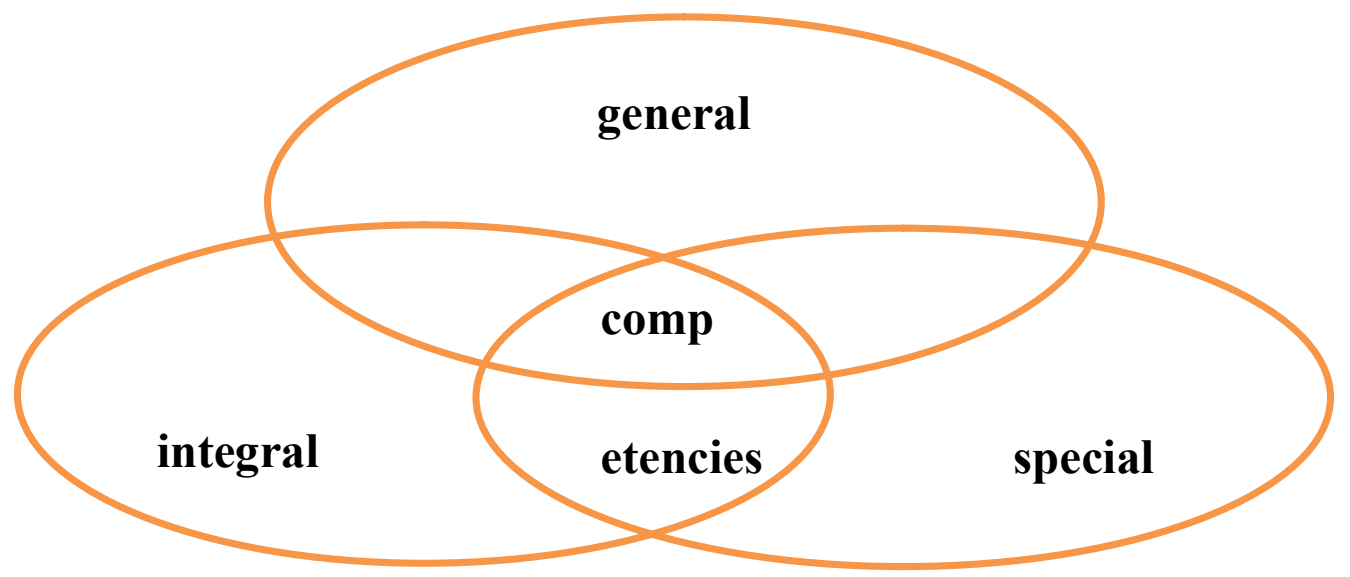

Fig. 1. Three blocks of competencies of intending primary school teachers for "Bachelor" educational level

The description of the National Qualifications Framework (NQF) [14] is used as the basis for determining the integral, general and special competences of educational and

$\begin{array}{lcr}\text { qualification } & \text { levels. } & \text { National } \\ \text { Qualifications } & \text { Framework is a } \\ \text { systematic and structured by } \\ \text { competences } & \text { description } & \text { of } \\ \text { qualifications. The NQF is structured in }\end{array}$


10 levels according to knowledge, skills, communication, autonomy and responsibility. Knowledge in the analysed document is defined as meaningful and learned by the subject scientific information, which is the basis of his / her deliberate purposeful activity. Knowledge is divided into empirical (factual) and theoretical (conceptual, methodological). Skills are explained as the ability to apply knowledge to accomplish tasks and solve problems. Skills are divided into cognitive (intellectual-creative) and practical (based on skill using methods, materials, instructions, means and tools). Communication is interpreted as the interconnection of subjects for the purpose of information transfer, coordination of actions, joint activities. Autonomy and responsibility are semanticized as the ability to perform tasks on their own, to solve problems and to be responsible for the results of their activities [14].

The article 35 of the Law "On Amendments to Certain Legislative Acts of Ukraine on Improving Education Activities in the field of Higher Education" [6] states that "the national qualifications framework is intended to streamline educational and professional qualifications. The number of qualification levels of the National Qualifications Framework corresponds to the number of levels of the European Qualifications Framework (EQF). This document is intended for use by public authorities and local self-government bodies, institutions and organizations, educational establishments, employers, other legal entities and individuals for the purpose of creation, identification, correlation, recognition, planning and development of qualifications. The national qualifications framework is based on European and national standards and principles of quality assurance of education, takes into account the requirements of the labour market for the workers' competences and is introduced with the aim of harmonization of legislation in the fields of education, social and labour relations, promoting national and international recognition of qualifications obtained in Ukraine, establishing effective interaction between education and labour market" [6].

Higher education standard is a set of requirements for higher education programs that are common to all educational programs within a given higher education level and specialty. This document is developed for each level of higher education within each specialty in accordance with the National Qualifications Framework and is used to determine and evaluate the quality of higher education and the results of educational activities of higher education institutions, learning outcomes in the relevant specialties. Higher Education Standard defines the following requirements for the educational program:

1) the amount of ECTS credits required to obtain an appropriate higher education degree;

2) requirements for the education level of persons who can start training under this program and the results of their training;

3) the list of mandatory competencies of a graduate;

4) the normative content of training for higher education applicants, formulated in terms of learning outcomes;

5) the forms of certification for higher education applicants;

6) requirements for the creation of educational training programs in the field of knowledge, two branches of knowledge or a group of specialties (in the standards of the junior bachelor's level), interdisciplinary educational and scientific programs (in the standards of master's and doctor's degrees);

7) the requirements of professional standards (if available) [10].

The analysis of general and special competences made it possible to 
emphasize the importance of forming philological (foreign language), communicative, socio-cultural and methodological competences. Within the framework of the normative content of the higher education applicants training, formulated in terms of the learning outcomes, the abilities to design the course of the subject; to model the process of teaching primary school pupils: to develop projects of lessons and their fragments, methods of work on certain types of tasks, create a methodology of preparatory work, acquaintance and formation of ideas and concepts, skills in order to master certain elements of the program content by pupils; to monitor and evaluate pupils' learning outcomes according to the assessment criteria and in accordance with state requirements for the level of pupils' academic achievements identified in the foreign language program are distinguished among professional and foreign language skills [5].

When analysing the draft of higher education standard, it should be noted that communication as a result pervades all competencies, beginning from general education and finishing with subject-related one. All competencies of intending primary school teachers are formed and developed in the process of studying by future specialists of all cycles' educational courses of general and professional training, the courses of educational institution choice, and the courses of students' independent choice. The tasks of teaching, education and development of primary school pupils are solved using communicative means, since any pedagogical or methodical task is solved as communicative [10].

Considering the specifics of the field of knowledge "Primary education" and the analysed state documents, we can conclude that the entire documentation base focuses on the professional training of a specialist in the development of his / her foreign language communication competence, which, in turn, is a cross-cutting and basis for successful self-realization as a citizen and a specialist.

On the basis of national governmental documents, we made an attempt to define the concept of "foreign language communicative competence of the intending primary school teacher". In our opinion, this competence is a dynamic, integrated personalprofessional combination of knowledge, abilities, skills, ways of thinking, attitudes, values, and other personal qualities, which determines the ability of a person to successfully socialize, carry out professional and further educational activities in the situations of foreign language communication and provides an opportunity for effective interaction both in terms of professional need, and for the selfeducation and self-development of an intending teacher.

In order to create a holistic picture of the forming foreign language communicative competence in recent years, in addition to the analysis of state documents, our study provides an overview of the real state of forming future primary school teachers' foreign language communicative competence, including analysis of educational programs of students' professional training of specialty 013 "Primary education" in Ukraine.

The Law "On Higher Education" states that an educational (professional, educational, scientific or educationalcreative) program is the only set of educational components (courses, individual tasks, practices, control measures, etc.) aimed at achieving learning outcomes according to the program that entitle individual to a specific educational or educational and professional qualification(s). An educational program may define a specialization within it or may not include specialization. Specialization is a component of a specialty that can be 
determined by a higher education institution and involves one or more specialized higher or postgraduate education programs [4].

Specialty is a harmonized within the International Standard Classification of Education subject area of education and science, which integrates related educational programs that provide common requirements for the competencies and learning outcomes of graduates [6].

According to the Concept of developing pedagogical education [9] higher education institutions can independently determine the subject specialties, specializations and additional specializations and implement them within the educational programs of the appropriate level. The Ministry of Education and Science of Ukraine establishes the rules for combining specialties, subject specialties and specializations in educational programs and defines the subject specialties under which state support is granted.

Higher education programs in the specialty 013 "Primary education" may include training in the second specialty, for example 012 "Preschool education", 016 "Special education", 024 "Choreography", 053 "Psychology" or 231 "Social work" or additional specialization. In the process of receiving the educational programs of the first (bachelor's) and second (master's) levels of higher education on specialty 012 "Pre-school education" and 013 "Primary education" it is expedient to receive simultaneously and to provide the acquisition of the third specialty or additional specialization (considering the European experience it is possible to consider the creation of a single specialty "Preschool and Primary Education"), which will be in line with the concept of mother school at these levels) [9].

Most pedagogical universities at the first (bachelor's) level of higher education in the specialty 013 "Primary education" in the field of knowledge 01 Education / Pedagogy provide educational qualification "Bachelor of primary education" and professional qualification "Primary school teacher". In addition, many of them provide additional qualification for the specialization, such as "Primary school art teacher", "Assistant teacher of a comprehensive educational institution with inclusive and integrated education", "Early and preschool children teacher", "Psychologist" (Mykhailo Kotsyubynsky Vinnytsia State Pedagogical University); "Foreign language teacher of primary school (English)", "Music teacher of primary school", "Computer science teacher of primary school" (Oleksandr Dovzhenko Hlukhiv National Pedagogical University), "Kindergarten teacher" (Drahomanov National Pedagogical University); "Teacher of Fine Arts" (Ivan Franko Drohobych State Pedagogical University); "Kindergarten teacher" (Borys Grinchenko Kyiv University); "Christian ethics teacher", "Foreign language teacher (English or German) of Primary School" (Bohdan Khmelnytsky Melitopol State Pedagogical University).

The educational program of training future primary school teachers is a state document, which defines the normative and selective content of education, sets the requirements for the content, amount and level of educational and professional training of a specialist in accordance with the Bachelor's Degree in specialty 013 "Primary education"; state and world community requirements are also generalized in it [17].

Higher education institutions independently develop and approve educational programs, taking into account the requirements for the appropriate higher education level established by the legislation and standards of higher education. Educational programs that provide for awarding the professional qualifications 
should ensure meeting the requirements of the relevant professional standards (if available), unless otherwise provided by law [6].

In accordance with reforming the primary education sector, the amount of the educational program for obtaining a bachelor's degree is determined by the higher education institution, which trains specialists in the relevant specialty, taking into account the methodological recommendations for the development of educational programs [15]. The main approaches to developing an educational program for teaching and learning are to take into account student-centered, professionallyoriented and communicatively-oriented approaches.

An important factor of the educational program for the future primary school teacher training is the distribution of the content of the educational program and the determination of the maximum education time in the cycles of training. In order to determine the content of professional training of the future primary school teacher, we conducted an examination of educational and professional training programs of a number of higher education pedagogical institutions in Ukraine: Drahomanov National Pedagogical University (2018), Mykhailo Kotsyubynskyi Vinnytsia State Pedagogical University (2018), Ivan Franko Drohobych State Pedagogical University (2017), Borys Hrinchenko Kyiv University (2017), Taras Shevchenko Chernihiv State Pedagogical University (2017), Oleksandr Dovzhenko Hlukhiv National Pedagogical University (2017, 2018). Analysis evidenced the educational programs basically include cycles that provide a certain educational level. The number of hours aimed at studying the cycles of courses varies within the following: general training from 1890 till 2000 hours (35 ECTS credits); professional training - 1836 hours (34
ECTS credits); professional and practical training - 5562 hours (103 ECTS credits), 1890 hours of which (14 ECTS credits) for the selective part of the educational program, 756 hours (14 ECTS credits) for different types of practices.

The analysis of the courses of general and professional cycles of educational program makes it possible to conclude that there is foreign language philological and linguadidactic training of future specialists during the study at higher education establishment. In most universities the average number of hours spent for learning a foreign language is 5 ECTS credits (150 hours); methods of teaching a foreign language in primary school - 4 ECTS credits (120 hours).

A particular focus of our attention is the professional cycle. It is the most extensive cycle of educational program. For research it is important to note that developing the professional communication skills, which make up the complex of the operations that allow realizing the formative function of professional communicative activity of a teacher in the practice of teaching at Primary Education Faculty, is provided by means of different courses. Thus, communicative training future primary school teachers in the system of professional education in a pedagogical university is carried out in the process of mastering both psycho-pedagogical courses (General Psychology, Children Psychology, the Basics of Pedagogical Mastery, Pedagogy, History of Education, Education Activity Methods) and linguistic, lingua-didactic teaching methods ("Professionally Oriented Ukrainian", "Contemporary Ukrainian Practicum", "Children's Literature", "Methods of Teaching Ukrainian", "Teaching Reading Methods", "Fundamentals of Oral and Written Language Culture".

But it is worth noting that most of them relate to the forming Ukrainianlanguage competence, and only one 
discipline (although called differently in different universities), in the course of which it is possible to form a foreign language communicative competence of intending primary school teachers, the number of credits for the study of which ranges from 5 to 11 , namely Foreign language, which is a discipline of the of general training cycle (elective discipline of higher education establishment choice) and is taught on the first course during the first semester (5 ECTS credits, 150 hours) (Oleksandr Dovzhenko Hlukhiv National Pedagogical University), or Foreign Language for Professional Purposes (11 ECTS credits, 550 hours) (Kotsiubynskyi Vinnytsia State Pedagogical University). In addition, in some higher education establishments, among normative disciplines of professional training cycle includes there is "Practice of Oral and Writing Speech (Foreign Language)" (Oleksandr Dovzhenko Hlukhiv National Pedagogical University), which is studied on the 2 or 3 courses ( 3 or 5 ECTS credits) as the continuation of the course "Foreign Language" or "Foreign Language for Professional Purpose", which in our opinion is appropriate and useful for the forming foreign language communicative competence of intending primary school teachers. In addition, some universities have courses of higher education establishment choice, such as "Foreign Language and Teaching Methods" (Drahomanov National Pedagogical University) or the course of the student independent choice "Business Foreign Language" (Drahomanov National Pedagogical University).

The analysed cycle is being expanded and supplemented by a number of courses and seminars at the choice of higher education institutions and students. The selection block for the Bachelor's degree is formed taking into account the first (main) specialty or specialization, scientific schools, professional interests of teachers, the complex scientific topic of the department, etc. [17].

The analysis of educational programs of training future primary school teachers and curricula made it possible to distinguish the courses that have objectively laid out opportunities for the forming foreign language communicative competence, in the process of studying of which according to modern requirements, integration with the foreign language can be used (Table 1). The proposed table was created on the basis of the reflection of the curricula of the previously mentioned higher education institutions of Ukraine.

Table 1.

Courses that may have the potential of forming foreign language communicative competence in the professional training of future primary school teachers

\begin{tabular}{|c|c|c|c|c|c|c|}
\hline \multirow[t]{2}{*}{ Course } & \multirow[t]{2}{*}{ NC } & \multirow[t]{2}{*}{ SC } & \multicolumn{4}{|c|}{ Year of study } \\
\hline & & & $\mathbf{I}$ & II & III & IV \\
\hline $\mathbf{1}$ & 2 & 3 & 4 & 5 & 6 & 7 \\
\hline \multicolumn{7}{|c|}{ General training cycle } \\
\hline Foreign language & & + & + & & & \\
\hline Ethics and aesthetics & & + & & & + & \\
\hline Innovative technologies in education & & + & & & + & \\
\hline $\begin{array}{l}\text { Foreign language for professional } \\
\text { purposes }\end{array}$ & + & & + & + & & \\
\hline \multicolumn{7}{|c|}{ Professional training cycle } \\
\hline $\begin{array}{l}\text { Practice of oral and writing speech } \\
\text { (Foreign language) }\end{array}$ & + & & & + & & \\
\hline
\end{tabular}




\begin{tabular}{|c|c|c|c|c|c|c|}
\hline Children's literature & + & & + & & & \\
\hline Foreign language teaching methods & + & & & & + & \\
\hline $\begin{array}{l}\text { Fundamentals of oral and written } \\
\text { speech culture }\end{array}$ & + & & & + & & \\
\hline $\begin{array}{l}\text { Fundamentals of speech culture and } \\
\text { technique, calligraphy }\end{array}$ & + & & & + & & \\
\hline $\begin{array}{l}\text { Rhetoric and Rhetoric Course } \\
\text { Methodology }\end{array}$ & & + & & & & + \\
\hline Rhetoric & & + & & & & + \\
\hline Ethics and aesthetics & & + & & & + & \\
\hline Family pedagogy & & + & & + & & \\
\hline $\begin{array}{l}\text { Theory and methodology of school } \\
\text { interaction with families }\end{array}$ & & + & & + & & \\
\hline $\begin{array}{l}\text { Methodology of primary school pupils' } \\
\text { playing organization }\end{array}$ & & + & & & + & \\
\hline $\begin{array}{l}\text { Organization of primary school pupils' } \\
\text { collective forms of activity }\end{array}$ & & + & & & + & \\
\hline $\begin{array}{l}\text { Foreign language and its teaching } \\
\text { methodology }\end{array}$ & & + & & & + & \\
\hline Business foreign language & & + & & & & + \\
\hline Culture of professional speaking & + & & & & & + \\
\hline Modern children's literature & + & & + & & & \\
\hline
\end{tabular}

Acronyms in the table: $N C$-normative course, $\mathrm{SC}$ - selective course

Conclusions and research perspectives. The analysis of national documents convinces their focus on the implementation of social order, in particular, the forming foreign language communicative competence in the process of professional training of future primary school teachers in higher education institutions of Ukraine.

Educational programs of a number of higher education pedagogical universities gives grounds to state that professional training educational programs of bachelors on specialty 013 "Primary education" are aimed at realization of state requirements for forming future primary school teachers' foreign language communicative competence. The didactic potential of a number of the courses that ensure forming the studied quality is aimed at it.

We see the prospects for further research in the process of exploration of the available educational and methodological support of the forming a foreign language communicative competence in higher education pedagogical institutions.

\section{REFERENCE (TRANSLATED \& TRANSLITERATED)}

1. Haluzevy standart vyshchoyi osvity.

kharakterystyka bakalaura za spetsialnistyu 6.010100 "Pochatkove navchannya" [Industry standard of higher education. Educational qualification characteristics of the bachelor in the specialty of 6.010100 "Primary education"]. (2006). Akad. APN Ukrayiny V.I. Bondar (Ed.). Kyiv, 57 [in Ukrainian].

2. Haluzevy standart vyshchoyi osvity. Osvitno-kvalifikatsiyna prohrama pidhotovky bakalavra za spetsialnistyu 6.010100 "Pochatkove navchannya" [Industry standard of higher education. Educational and qualification program of training the bachelor in the specialty of 6.010100 "Primary education"]. (2006). Akad. APN Ukrayiny V.I. Bondar (Ed.). Kyiv, 140 [in Ukrainian]. 
3. Derzhavna prohrama "Vchytel" na 2018-2020 roky. [Teacher State Program for 2018-2020]. Retrieved from https://rada.info/upload/users_files/4 1779881/200fd37d6795d8f15aa1ddd7 1b215ffo.docx [in Ukrainian].

4. Common European Framework of Reference for Languages: Learning, Teaching, Assessment. Retrieved from www.coe.int/lang-CEFR [in English].

5. Zakon "Pro vnesennya zmin do deyakykh zakonodavchykh aktiv Ukrayiny shchodo vdoskonalennya osvitnoyi diyalnosti u sferi vyshchoyi osvity" [Law "On Amendments to Certain Legislative Acts of Ukraine on Improving Higher Education Educational Activities"]. mon.gov.ua. Retrieved from https://mon.gov.ua/en/news accessed 03/25/2020 [in Ukrainian].

6. Zakon Ukrayiny "Pro vyshchu osvitu" vid 01.07.2014. № 1556-VII. [The Law of Ukraine "On Higher Education" of 01.07.2014, № 1556-VII. zakono.rada.gov.ua. Retrieved from http://zakon0.rada.gov.ua/laws/show/ 2145-19 [in Ukrainian].

7. Zakon Ukrayiny "Pro osvitu" vid 05.09.2017. № 2145-VIII. [The Law of Ukraine "On Education" of 05/09/2017. № 2145-VIII. zakono.rada.gov.ua. Retrieved from http:/ / zakon0.rada.gov.ua/laws/show/ 2145-19 [in Ukrainian].

8. Kontseptsiya realizatsiyi derzhavnoyi polityky u sferi reformuvannya zahalnoyi serednoyi osvity "Nova ukrayinska shkola" na period do 2029 roku № 988-r. [The concept of realization of state policy in the sphere of reforming general secondary education "New Ukrainian School" for the period up to 2029 № 988-p. kmu.gov.ua. Retrieved from https://www.kmu.gov.ua/uanpas/249 613934 [in Ukrainian].

9. Kontseptsiya rozvytku pedahohichnoyi osvity Ukrayiny vid 16.06.2018. № 776. [The concept of developing pedagogical education of Ukraine $\quad 16.0618 \quad$ № 776. http://oipopp.ed-sp.net. Retrieved from http://oipopp.ed-

sp.net/public/attached_files/5b7bb2dc c424a809787929.pdf [in Ukrainian].

10. Proyekt standartu vyshchoyi osvity za spetsialnistyu 013 "Pochatkova osvita". [Higher Education Standard Project on Specialty 013 "Primary Education"]. mon.gov.ua. Retrieved from https://mon.gov.ua/ua/osvita/vishaosvita/scientific-metodichna-radaministerstva-osviti-i-naukiukrayini / proekti-standartiv-vishoyiosviti [in Ukrainian].

11. Metodychni rekomendatsiyi shchodo rozroblennya standartiv vyshchoyi osvity vid 21 hrudnya 2017 № 1648. [Guidelines for the developing higher education standards dated December 21, 2017 № 1648]. mon.gov.ua. Retrieved from https://mon.gov.ua/storage/app/medi a/vishcha-osvita/rekomendatsii1648.pdf [in Ukrainian].

12. Natsionalna stratehiya rozvytku osvity v Ukrayini na period do 2021 roku vid 25 chervnya $2013 \mathrm{r}$. № 344/2013. [National Strategy for the development of Education in Ukraine for the period up to 2021 of June, 25, 2013. No .344/2013]. zakono.rada.gov.ua. Retrieved from http: / zakon0.rada.gov.ua/laws/show/ 344/2013. [in Ukrainian].

13. Pro zatverdzhennya derzhavnoho standartu pochatkovoyi zahalnoyi osvity: Postanova kabinetu ministriv Ukrayiny vid 21 lyutoho 2018. № 87. [On approval of the State Standard of Primary General Education: Resolution of the Cabinet of Ministers of Ukraine. February 21, 2018. No. 87. www.kmu.gov.ua. Retrieved from https://www.kmu.gov.ua/en/npas/pro -zatverdzhennya-derzhavnogostandartu-pochatkovoyi-conquer [in Ukrainian].

14. Pro zatverdzhennya natsionalnoyi ramky kvalifikatsiy vid 23 lystopada 2011. № 1341. Iz zminamy, vnesenymy zhidno $Z$ postanovoyu 
№ 509 vid 12.06.2019. [Approval of the National Qualifications Framework of November 23, 2011. No. 1341]. Kyiv. zakon.rada.gov.ua. Retrieved from https://zakon.rada.gov.ua/laws/show/ [in Ukrainian].

15. Profesiyny standart "Vchytel pochatkovykh klasiv zakladu zahalnoyi serednoyi osvity" vid 10.08.2018. № 1143 [Professional standard "Primary school teacher of secondary education" dated 10.08.2018. № 1143 . www.msp.gov.ua. Retrieved from https://www.msp.gov.ua/files/News / 2 0180815/20180815.pdf [in Ukrainian].

16. Rekomendatsiya 2006/962/€C Yevropeyskoho Parlamentu ta Rady (EU) "Pro osnovni kompetentsiyi dlya navchannya protyahom usoho zhyttya"
[Recommendation 2006/962/EU of the European Parliament and of the Council (EU) "On basic competences for lifelong learning"]. (December, 18, 2006). zakon.rada.gov.ua. Retrieved from

https://zakon.rada.gov.ua/laws/show/ 994_975 [in Ukrainian].

17. Rozroblennya osvitnikh prohram. Metodychni rekomendatsiyi [Development of educational programs. Guidelines]. (2014). V.H. Kremen (Ed.). Kyiv: State Enterprise "Priorities", 120 [in Ukrainian].

Received: March 19, 2020

Accepted: April 15, 2020 